Available online at website : http://e-journal.adpgmiindonesia.com/index.php/jmie JMIE: Journal of Madrasah Ibtidaiyah Education, 3(2), 2019, 142-167

\title{
THE DYNAMICS OF INTEGRATED CHARACTER DEVELOPMENT \& ENGLISH LITERACY IN THE INCLUSIVE EDUCATION SYSTEM IN PRIMARY SCHOOL IN THE ERA 4.0
}

\author{
Zidniyati \\ Institut Agama Islam Ibrahimy Genteng, Banyuwangi \\ Email: taravizidni@gmail.com \\ Naskah diterima : 25 Agustus 2019, direvisi : 15 September 2019, disetujui : 25 September 2019
}

\begin{abstract}
This paper is the result of research into the application of character education and English literacy that is integrated in the inclusive education system in Tabita Puri Elementary School, Genteng-Banyuwangi. This research was conducted based on the need to look at whether the application of inclusive education at the elementary school level. In this study, what was observed was the application of inclusive education in one private primary school. The research method was conducted in a descriptive qualitative manner. Data obtained through observation, interviews, and recording school documents. The data extracted is data about the ability of teachers to carry out an inclusive system in teaching and learning. The research aims to describe what are (a) the constraints experienced, (b) the supporting factors to achieve the targets, and (c) the challenges faced for the implementation of inclusive education. The results of the study showed that obstacles in implementing inclusive education were the lack of teachers 'ability to implement the inclusive education system and the lack of teachers' ability to speak English. The supporting factors for organizing inclusive studies in this study were the development of character education to create school culture of mutual respect. The challenge faced is finding ways to strengthen teacher skills in organizing inclusion and English language skills.
\end{abstract}

Keywords: Character Development, English literacy, Inclusive education, Era 4.0.

Pengutipan: . Zidniyati. (2019). The Dynamics of Integrated Character Development \& English Literacy in the Inclusive Education System in Primary School in the Era 4.0. JMIE: Journal of Madrasah Ibtidaiyah Education,3(2), 2019, 142-167. jmie.v3i2.129.

Permalink/DOI: http://dx.doi.org/10.32934/jmie.v3i2.129 


\section{INTRODUCTION}

Five years after Banyuwangi was declared an inclusive Regency, the condition of the school management system in Banyuwangi still left a considerable amount of homework for education observers. On August 27, 2014, Banyuwangi was declared as an inclusive Regency. The intended inclusion district is a district that provides educational opportunities for all children, both special educational need (SEN) students or not to be able to study in the same school, learn the same subjects, and participate in all activities in the school without discrimination. In the data sourced from the official website of the Banyuwangi district government dated August 27, 2014, there were 115 schools that recorded inclusive education. Of these 115 schools, there are 28 PAUD schools, 44 SD / MI, 26 SMP / MTs, 17 SMA / MA. It was also stated on the official website that the schools holding the inclusion were equipped with special tutors and accessible infrastructure for SEN students. One of the other objectives of the declaration of the Banyuwangi district as an inclusive school, as the Banyuwangi Regent's wishes at that time was that by having ABK studying in regular schools, Banyuwangi would be able to realize a child-friendly, non-discriminatory and tolerant education. This declaration is certainly good news for the world of education in Banyuwangi, especially the concept of inclusion that was launched is very broad educational services for all children.

However, how are the readiness of the educators and the entire management system of inclusive schools in Banyuwangi Regency? Can it be said "ready"? And how is the management system of the modification program and the learning process accommodation for each child, does it meet the needs of every child? How do you compare the availability of special assistant teachers with the number of students? Has the inclusive school established a governance system for creating character education that is suitable for implementation in an inclusive system? The answers to these questions are still largely in the "not yet ready" range. Of course, this answer still requires detailed data mining to be more accurate. This excavation process will be planned to be carried out in the research process later. However, the answer "is not yet fully prepared" is based on the acquisition of data in a small scope based on the application of inclusive education in the organizing school, in the District of Genteng. Not all schools have one trained teacher trained as planned by the Banyuwangi district government related to inclusive education program. In addition, modification and accommodation programs for students with special needs have not been well programmed, and there are even schools that do not have programs for students with special needs according to their needs. This was revealed from the statements of several parties from several secondary schools that these schools did not accept special need student as new students because there were lack of teachers with the ability to handle children with special needs, or for other reasons they did not dare to accept because there were no programs specifically planned for ABK. Several other schools stated that they only accept special need student who are academically capable 
of attending academic activities in regular schools, it means that their specificity is physical specificity, their academic abilities are normal. This last statement certainly also contradicts the principle of "school for all children".

Another thing to note is to prepare students to be ready to navigate life in the times of the industrial revolution. As it is known that people who lived during the 4.0 industrial revolution were required to be able to interact with the whole world community, not just one country, given the speed and ease of communication processes between residents of all corners of the world. One of the tools of international communication is English language. Educators must also consider this, that every student who is currently in elementary school, will experience a world that is much faster and more modern in the next 5 to 10 years. Under the condition, an appropriate planned management is needed and in accordance with the conditions in the field, how can students be actively communicating in English.

The theoretical study proposed in this paper includes a study of inclusive education and character education development. This paper also gives a theoretical study of the outline of understanding the industrial revolution 4.0. In the study of inclusive education discussed about the nature of up to several things that are needed in the application of the inclusive education system. The study of character education in this paper includes the definition and affirmation of the importance of character development related to the application of inclusive education at the elementary level. The discussion of the industrial revolution 4.0 is outlined in stages of the noble industrial revolution 1.0 to 4.0 and this discussion is given to find out what skills students need to master in the 4.0 era.

The research method was conducted in a descriptive qualitative manner. Data obtained through observation, interviews, and recording school documents. The data extracted is data about the ability of teachers to carry out an inclusive system in teaching and learning. The respondents involved in this study were 12 teachers at Tabita Puri Genteng Elementary School, Banyuwangi. The research was conducted in Februari up to April 2019. Observations were made to see the ability of teachers to implement lesson plans in inclusive classes. Observation of the document is carried out to see whether the learning plan includes a learning plan or Individual Educational Program (IEP) for students with special needs or not. Interviews were conducted with school principals and teachers for data triangulation efforts.

Data analysis was performed using an interactive analysis method developed by Miles and Huberman (2014). There are 3 stages proposed. First, data condensation to make it easier for researchers to collect data and look for it when needed. To be able to collect data and look for it when needed, researchers conduct activities to analyze, classify, direct, and dispose of unnecessary in such a way. One example is to look at the consistency of the informant's statement at the time of the interview and discard or combine data and facts that are 
duplicative at the time of the interview between one informant and another informant so that the final conclusions can be drawn and verified by researcher. Second, the data presentation is carried out by the researcher using several steps, including a brief description, charts and relationships between categories. Presentation of data in the form of brief descriptions, charts and relationships between categories makes it easy for researchers to see the overall picture or a particular section in this study which is then compiled in the form of narrative texts in sharp, decisive language, and do not cause double, objective, clear and concise interpretations. Third, draw conclusions or verify. After verifying continuously, from the beginning the researcher enters the location and during the data collection process, the next is to draw conclusions. This activity was carried out to analyze and look for patterns, themes, relationships, similarities, things that often arise, hypotheses, and so forth as outlined in conclusions. The steps taken were (a) outlining the problem, then giving a summary of everything that had been described, (b) connecting each data with the problem to arrive at certain conclusions in a research proposition, both on minor propositions and major propositions and (c) concluded by explaining and answering what is in the research formulation and research objectives. The data validity technique in this study is based on credibility and triangulation.

The degree of transferability in this study is the level of finesse as an empirical problem and depends on the similarity of perception and understanding between the context of the sender (researcher) and receiver (reader). To be able to create chaos, in research on implementing of inclusive education, researcher seek to present actual data by presenting careful and detailed descriptions and enabling the enrichment of concepts that can be applied in different places and situations. In the same way researcher also looked for references to previous research to be juxtaposed with research conducted by researcher. The degree of dependability is a dependency activity that can be used by researcher to check whether the research activities carried out are right or wrong. Furthermore, this process depends on how far the assessment of researcher conceptualizes the phenomenon of the application of inclusive education, because this is a reflection of reliability standards. Reliability standards are achieved when a thorough audit or thorough inspection is carried out through the process to the results. To be able to conceptualize the phenomenon under study, the researcher presents several forms of research narratives. Whereas the dependability process is carried out with: consistency in the inference of data, consistency in the formation and compilation of concepts as well as consistency in making interpretations and drawing conclusions. The degree of confirm ability is the activity of checking the accuracy of the data obtained by confirming and checking data on information obtained from several informants, juxtaposed. Therefore, the degree of certainty is determined by the reliability standard. The criteria are determined based on the concept of objectivity according to the approach. Because in this paper the type of research used is the type of qualitative research, so to ensure certainty, this 
research requires a long and selective observation and interview process to produce stability and consistency of data.

The research aims to describe what are (a) the constraints experienced, (b) the supporting factors to achieve the targets, and (c) the challenges faced for the implementation of inclusive education. The results of the study showed that obstacles in implementing inclusive education were the lack of teachers' ability to implement the inclusive education system and the lack of teachers' ability to speak English. The supporting factors for organizing inclusive studies in this study were the development of character education. The challenge faced is finding ways to strengthen teacher skills in organizing inclusion and English language skills

\section{CONTENT \& DISCUSSION}

Over time, now human civilization has entered the era of the industrial revolution 4.0. An era in which information and communication between humans living in the northern and southern hemisphere became very fast and felt close. Through internet-based network access, all information needed by humans can be obtained only by utilizing devices equipped with high-level Android facilities by searching the virtual world using a search engine. It does not take long, enough in seconds, various information and transactions until decision making can be done. Through this form of communication, all business transactions can be carried out quickly and far more efficiently than conventional methods. All forum discussions can be done remotely, all decisions can be taken even if the discussion members are in different places. Details of a product can be packaged in a visual image with clear audio facilities, so that a manufacturer can advertise his product and potential customers can see it by searching an information search engine. Adult humans, teenagers, and children today can be connected and can access various information from all corners of the world. The digital age is used as a term that represents the conditions referred to. How educational institutions can carry out their roles appropriately in this era of digital revolution of the all-digital industry?

The following is discussed in a coherent manner regarding the application of: character education, inclusive education, English literacy, and inclusive education by strengthening character education and English literacy in elementary school in the era of industrial revolution 4.0 .

\section{The Implementation of Character education in Tabita Puri Elementary School}

Based on the indepth interviewed with the headmaster of Tabita Puri Elementary School, Ustadz Jarkoni, S.Pd, the mplementation of character education programs in Tabita Puri Elementary School is based on the principle of instilling values and ends in habitual 
behaviour and act according to the values used as guideline. The headmaster said that all values embedded in this school are centered on 3 aspects, which are: (a) for the purpose of creating good relations with the Creator, (b) for the purpose of creating good relations with fellow beings, and (c) for the purpose of creating good relations with nature and everything in it.

\section{a. For the purpose of creating a good relationship with The Creator}

For this purpose, the school apply the value of observance of worship. Its application is done with a pattern of habit of worship starting at the beginning of school hours until the end of school every day. This habit is seen in the habit of performing wudlu, praying, and praying / dhikr. During the first 3 years, in grades 1, 2, and 3, all students made a habit of praying with reading aloud. This is done so that students hear the readings in every prayer movement every day. The target of this habituation activity is students will memorize prayer readings according to the ability level of each student. Likewise what is done in the habit of reciting daily prayers / dhikr. The way to do this is to get in the habit of listening to prayers, imitating prayers, and praying every day according to their respective abilities. This habituation is carried out during the first 3 years, with the reason that each student has different ability to remember, some students are fast in remembering the material, some are slow.

\section{b. For the purpose of creating good relations with fellow beings}

For this purpose the school apply two basic values, which are the value of respect and responsibility. Various development values of the two basic values include love, respect, care, cooperation, and honesty. All of these values are included in the curriculum and culture at school and at home. One of the values instilled is honesty. Every student is accustomed to being honest in doing their assignments. To support the achievement of the value of honesty flourishing in students, the teachers also instill confidence in each student. The effort made by the teacher is to appreciate all the work of students, and the teacher measures the work of students without comparing with the work of other students. The real form in this case is not applied to class ranking. The ranking system in question is comparing student scores with other students. This is applied with the aim, students are able to measure their abilities today, and are able to make progress for tomorrow. In their daily lives, students who still get low marks will be guided to make improvements. The results of implementing this kind of system turned out to be very good. In June 2019, 1 alumni received the best predicate from 300 of 7th grade students at SMPN 1 Genteng. 1 alumni won the best achievement of 500 students at the Bumi Sholawat Sidoarjo Progressive Junior High School. 1 alumni won the second best ranking in their class at Bustanul Makmur Genteng Junior High School. The achievements shown by the three alumni have made the school strength to further strengthen the character development program. Schools also draw a conclusion that, the level of resilience of students in dealing with a situation also needs to be trained more regularly and systematically while 
studying at the elementary school level because it turns out that this is very much needed by a student in attending the process of further learning in years later.

Another example is the teacher will pair students who understand the material faster with students who are slower. This is done for the sake of developing the value of caring for friends. The activities carried out in the program for teachers for students include recording everything that happens to students throughout the day while at school. This recording is included in the anecdotal record. Another example is to get the younger siblings to say 'big brother' to the big brother. The school's effort in creating good relations with others is to establish communication with each parent, especially in the context of achieving targets for each student. Gift-sharing activities on Islamic holidays are also held at school. Usually, the school will prepare a simple gift which will be distributed by all students to all the poor who live in the area around the school.

Character becomes something that is highly considered in this school. Every attitude that is raised by every student will get the full attention of every teacher. When a student shows an attitude that is not in accordance with the rules, for example, students say disrespectful words, then the teacher will invite the student to discuss what he has said. This effort was made to instill understanding in students themselves. For younger students, in grades 1, 2, and 3, teachers will usually immediately give examples to say toyyibah sentences (good sentences) for students who forget to say them. For example, if there is a grade 1 student who forgets to say hello when he wants to enter class, the teacher will warn students by saying greetings. When this is done by the teacher, students immediately say hello as the teacher says.

\section{c. For the purpose of creating good relations with the nature and everything in it}

For this purpose the school develops two basic values, which are the value of respect and responsibility. The development of the two values is directed at the value of caring for the environment, compassion for animals and plants that are around the school. The activities that are used as media for developing these values are by providing routine assignments for each student to look after various plants in the school, feeding animals in the school area, throwing trash in their place, cleaning the dining area after lunch, washing cutlery after snack time and lunch.

\section{The Problems}

Achieving the target of the character development program in this school does not mean that it does not leave any problem. Some problems arise when some parents complain that their children are quite slow in showing the ability to behave politely, responsibly, and in an orderly manner. Every year, a parent meeting is held, precisely at the beginning of the 
second month of the first year of school. Some parents always complain about how slowly their children are showing a positive attitude. Some parents complain about why their children do not want to study while at home. Some other parents complained that their children did not progress in reading the Qur'an. Some parents complained why there were no daily tests to evaluate the academic abilities of their children. The rest ones filed complaints on how children did very often spend time at home playing online games on their gadgets.

These complaints were responded quickly by the school by looking back at each anecdotal record compiled by each teacher. The results obtained are then matched with student behavior both at school and at home. Most students show progress and follow activities well in school, while most students show the opposite attitude while at home. This was followed up with a small discussion between parents, class teachers and psychologists, for urgent cases, for example for the case of students who spend more time at home playing online games on gadgets. For other cases, usually the psychologist will suggest waiting for students to show progress in a period of up to one month in the future. Some consequences are of course taken to achieve progress, including that teachers and parents must have the same target and the same program implemented both at school and at home.

\section{The Challenges}

The challenge in implementing the character development program in this school is the adjustment of the program at home and at school. Often, some programs implemented at school are uncommunicated to parents at home. Seeing this case, what needs to be improved is the development of a better communication between the school and the parents. This communication improvement also needs to be done in an effort to convince parents that the problem of character development is not a case that can quickly produce results. When there are some students who are quick in showing positive character, it does not mean that other students are also able to quickly demonstrate positive behavior.

\section{CORE DISCUSSION}

The implementation of character education in Tabita Puri remained us to what Lickona has expressed, that character education starts from introducing the concept of a value, then attempts to convince students that the value is a guideline held in life, and ends in habitual behavior and act according to the values used as the guidelines. The program carried out refers to the living values program. Although the implementation is not yet fully in accordance with the procedures in the living values program as a whole, in general the efforts made at this school have been going well. Character education itself contains the education of the values of character builders, especially activists of the LVE (living values education) 
program argue that for several centuries character education has been carried out, it still has not yielded maximum results. This happens because of several reasons, including the value education program that has not been implemented holistically. Diane Tillman (2016: 10), one of the initiators of the LVE program and her team formulated the LVE program which aims to provide guiding principles and tools for human development holistically so that each individual has (1) skills honed in terms of intrapersonal and interpersonal both social and emotional, and has (2) perspective and value-based behavior.

What Tabita Puri's elementary school has done, can also be categorized as a program to revive the values proposed by Dianne Tillman, especially when viewed from the program being developed which is based on 3 division of values development goals, namely for the purpose of creating a good relationship with the Creator, with fellow beings, and good relations with nature and everything in it. Drake who also supports the Living Values Programme divides the three elements (2016: 12) namely: (1) principles in the teaching and learning environment, (2) principles about teaching values, and (3) the principles related to the nature of each individual in the world context and scope of education, it is definitely needed the formulation of character education management that carries the value education program. As to whether management is meant, of course, which contains the 3 main principles. The three main divisions applied at Tabita Puri Elementary School also seem to have the same principle proposed by Drake. The core of these principles is the importance of a school creating an environment that can develop values of virtue, the importance of applying the principles of learning the values of virtue, and the importance of applying natural principles so that the values learned by students can be attached to students and can be easily applied to the context of life that suits students' daily lives. In a study conducted by Depiyanti (2014) also mentioned that the habituation model and direct experience for character education are also very appropriate for students, this is also the same as that obtained in this study, that character education at the research location is also carried out using the habituation principle and by presenting hands-on experience. The difference between this research and this research is on the subject and location of the study. The research was conducted at Cendikia Elementary School in the city of Bandung, West Java. In terms of the method of character development in the study carried out using the $4 \mathrm{~h}$ system which stands for the values of character education developed. ther research was conducted by Murniyetty, Engkizar, and Fuad Anwar (2016). In that study it was found that character development was successfully carried out in elementary school students through learning activities, extracurricular activities, and religious activities in schools. The difference between Murniyetty, Engkizar and Fuad Anwar's research and this research lies in the focus of the study. In Murniyetty, Engkizar, and Fuad Anwar's research, the focus is on character trailing, whereas this study focuses on character development, inclusive education, and English literacy. Although different, there will be a principle similarity between the two previous studies and this research, that character education is successfully 
carried out with the habituation method and is naturally integrated in all activities at school, it is not something taught separately.

The living values education is seen as an effort to carry out character education based on the principle that every human being has a seed of goodness, and the living values program seeks to revive (re) that goodness. How to formulate character education management in which living values education can be applied, will be a further study in this research. The concept of value education which is divided into 3 domains according to the Lickona concept (knowing values, feeling values, and acting values) is the main basis of the virtue education principle in this study. Whereas the theory of comprehensive approach in the value education from Kirschenbaum (1995: 31) is applied to help the delivery of value education techniques to students so that later they can live a satisfying life personally and a socially constructive life. There are four categories of Kirschenbaum's comprehensive values education, namely: instilling values and morality; model values and morality; facilitate values and morality; and skills for the development of values and moral literacy.

The approach taken by Tabita Puri elementary School in applying character development is also in line with the comprehensive approach proposed by Kirschenbaum. Starting from the inculcation of values, setting an example of how to apply these values, facilitating all school members by applying the situation of habituating the values of worship and other virtues for all students, and at the same time developing the skills of applying values in daily life. Beyond a very natural situation as presented by the school activities, it turns out the values of character development can be done well. During an interview with the principal of Tabita Puri Elementari School about why this school implemented a policy of developing values in the school on March 18, 2019, the principal explained:

"There is nothing that needs to be done by schools as educational institutions other than developing values that are certainly needed by every child in living his life to adulthood. So, in this school, the culture that is developed is also a culture of being polite. If not at school, where else will these children learn from of how to be polite? We are here obliged to provide opportunities for children in practicing the values of politeness learned, we also have to communicate to parents about this so that everything learned in school can also be applied at home. We hope parents at home who set an example to be polite. So that culture of being polite can be created at school as well as at home."

There is a belief in the principal that every student will be able to have a good attitude when set an example to do the good. That means, every student has a seed of goodness that can be developed. The effect of education is very strong on the character of children. This is also relevant with the ideas put forward by Ki Hadjar Dewantara who stated that the role of education indeed leads children to become personal with good character, because every child has been born with the seeds of goodness. When educators have completed their duties 
properly, the seeds of evil which are also born with children, can be ordained until they cannot grow and develop. This idea certainly convinces moral educators that it is possible to develop value education to develop good character in students. Ki Hadjar Dewantara (2013: 20), an educational figure in Indonesia who lived in 1889-1959 defined education as a guide in the life of growing children. If education is a guide, then the contents of education should be the values that are used as guidelines for life. According to Ki Hadjar Dewantara, education is intended to guide all the natural forces possessed by children, with the aim that children as humans and also as members of the community are able to achieve the highest safety and happiness.

According to Ki Hadjar Dewantara (2013: 22-23) the basic soul of a child can be influenced by education. The basis of the soul according to Ki Hadjar Dewantara is the state of the original soul according to its own nature. Child's nature is as a human being, with the influence of an education, a child will continue to grow into a human being, a good human being or a person who is not of good character. The effect of education is very strong on the character of children.

Pestalozzi, educational thinker, American philosopher, and social critic who lived in 1859-1952, also stated that humans are born with the seeds of goodness as quoted by Heafford (1967: 61), "Man is good and seeks the good; his conscience only allows him to feel secure when he does the good; and if he is evil, it is surely because the way has been blocked, along which he wants to be good." Based on this statement, Heafford means that every human being is born with the seeds of intellect within himself, then as such, every human being is born with the seed of human goodness. For this reason, the goal of all education is to care for this seed so that it grows and develops. Thus it can be reiterated that each baby is born by carrying the seeds of goodness and this seed is what follows during the course of his life must be cared for properly. This treatment will be carried out in various ways, including and most importantly, through education, both formal and informal.

Here it can be concluded that values as the core of character education can be done with the habituation method, done naturally, integrated with all activities carried out by students at school, and based on the belief that each child carries the seeds of goodness in himself, we, as adults, can foster and grow the seeds of goodness so that children can become mature humans with good personalities. However, the problem in character building education will occur if the program at school is not communicated with parents. Therefore, the challenge for character education development schools is the ability to establish communication with parents especially in communicating character education programs.

\section{The Implementation of Inclusive Education in Tabita Puri Elementary School}


Inclusive education at Tabita Puri Elementary School is marked by the assimilation of students with special needs in the learning process together with regular students in the same class. The level of specificity is relatively mild to moderate. At the time of observation, out of 106 students there were 3 students with ADHD (1 of them are $4^{\text {th }}$-grade students and the rest are $5^{\text {th }}$-grade students), 1 student with moderate category mental retardation (grade 4$), 1$ speech impaired student (grade 5), 1 student with difficulty of learning because of language constraints (grade 4$), 4$ student with mild slow learners $\left(1\right.$ is the $6^{\text {th }}$ grader, 1 student is $4^{\text {th }}$ grader, and 2 students of $1^{\text {st }}$ grader), 3 students of $6^{\text {th }}$ grader who were in disharmony of their parental relationships. For the $3^{\text {th }}$ grade students, the school did pay special attention to keep them motivated to learn and not be disturbed by harmonious parental relationships. The categorization of students with special needs is as proposed by Santrock (2008: 184) who classifies it into 8categories which are: learning disability, mental retardation, sensory disorder, autism spectrum disorders, attention deficit hyperactive disorders, physical disorders, speech and language disorders, and emotional and behavioral disorders.

In this study, the main sources of informants were 12 teachers who work together as a team in assisting students in inclusive classes and 1 school principal. In every class at this school 2 teachers are provided. These two teachers are working on mentoring for all students, specifically for students with special needs. Because teachers at this school do not have sufficient ability to do initial identification for students, the school is facilitated with psychologists to support the psychological assessment for all students. The results of this psychological assessment as an initial identification are used to collect the types of student needs.

The teachers in the class provide assistance in accordance with the results of preliminary observations from professional psychologists. In the learning process, there are some students with special needs who must take part in the school's intervention program. This intervention was carried out based on preliminary assessments from psychologists and periodic observations made by the teachers. One form of the intervention is a therapy program conducted in the therapy room at school. Therapy is done 3 times a week according to the specifics of each student. Therapy is carried out at certain hours between school hours, which starts at 08.00-12.00 WIB. Each therapy meeting is held for 1 hour for 1 child with special needs. At 13.30-15.00 WIB children with special needs attend the Koran reading program or physical exercise as part of an occupational therapy program. In addition to hours of therapy, all students with special needs learn and play together with regular students in the same place.

\section{The Progress}


Based on the results of various programs implemented in this school for every child with special needs, there is one thing that is most prominent from this school, that is the growth of mutual understanding among school members. All students, teachers, and employees have the same understanding of all students with special needs. Every school member is required to provide tolerance as well as assistance for every student with special needs. It aims to make students with special needs to feel accepted by all school members who do not have special needs. The result of all this is the growth of trust in each student with special needs.

Progress that arises from each student with special needs is very diverse, and this progress occurs in each student. For 1 of 4 students with ADHD, who at the beginning of the year still showed the attitude of often hitting friends while playing, in the third month of school they had greatly reduced the attitude of hitting their friends. In the first half of the year, the behavior of hitting friends was gone. Its concentration is far longer than the first year of school. At the end of the beginning of the fourth year, he was already independent in doing a number of things in learning activities, but still had to attend a therapeutic program.

At the beginning of the year, 3 other students with ADHD still had to get full mentoring by special mentor teachers because the concentration level was very short, in the middle of the year the concentration power had increased, which initially was only 3 minutes, to 5 minutes. At the end of the first year, 2 out of 3 students with ADHD were already independent, without much assistance from the teacher assistant. For 1 student with ADHD it takes until the end of the second year to be able to be independent without a co-teacher.

The level of progress for students with mild disabilities at this school lasts longer than students with ADHD. The accompanying teacher must accompany until this student steps on the end of the third year. At the beginning of the fourth year there is still a need for special teacher assistance. Willingness to write and read is still low. However, there is a progress that is very meaningful is the willingness of students to sit during the learning process and join the class with friends and teachers. In the first, second, and third years, students still find it difficult to participate in learning with classmates, but once in the fourth year, students are able to sit and participate in each activity, even though they do not want to write and read independently.

For students with non-permanent special needs, progress can occur when support from family members at home is very strong. These nonpermanent special needs include students whose relations are not harmonious or divorced. Some cases occur when parents work far away so that the roles and figures of parents are subtituted by the presence of other family members, such as grandmothers. With the absence of a figure and the role of a parent for some students, it can lead to certain special needs. As happened in this school, there is 1 student who has difficulty concentrating in learning. Some material is not mastered because of 
this kind of disturbance. An intervention that the school is able to do is talk to the student's family member. However, to meet or bring family to school is not an easy matter. In this case, further research is needed so that communication remains established.

\section{The Problems}

There are several problems in the implementation of inclusive education in this school. These problems is related the teachers' skills in doing the early identification and compiling Individual Educational Programme (IEP). The training program for special assistant teachers organized by the local government office also has never been followed. Based on an interviewed with the headmaster of this school, this is due to lack of communication with the local education officer. To overcome this, the school participates in some short training independently conducted by private organizers from various cities in Indonesia. However, teachers still have difficulty to assist students with special needs because they have not been able to compile an IEP. Based on the interviewed with the teachers, they found that different situations and contexts in fact also provide a challenge for them so that they faced difficulty when trying to apply the knowledge gained from training. The preparation of the Individual Educational Program (IEP) in this school also still has shortcomings. IEP should be arranged periodically, according to the short term, medium term, and long term, but in this school, the teacher didn't make any IEP. The teacher only made some anecdotal record beyond the observation of students with special needs.

One problem facing by this school is finding a junior high school as a continuation of basic education for students with special needs. The headmaster said that most junior high schools around Tabita Puri Elementary School are still not ready to accept students with special needs due to the absence of special programs for students with special needs. There are several schools that are ready to accept students with special needs, but unfortunately the schools only accepted students who have no intellectual obstacles. Some parents who have children with special needs are always thinking about this because they have not received certainty where schools that are willing to accept their children. During this time, the effort undertaken by the school was by communicating to the organizers of junior high schools. Tabita Puri Elementary School conveyed the specific conditions of the alumni directly and in writing to the organizer of the intended Junior High School. This effort did not necessarily get a positive response from the First Middle School. Two junior high schools frankly stated rejecting alumni with special needs on the grounds of the absence of special assistant teachers. One private junior high school stated that it did not accept students with special needs, at first. 
However, after several discussions about the specificity of the alumni, finally the private high school was pleased to accept the alumni with special needs under various conditions. Among these requirements are students with special needs who can be accepted are students who do not make any noise in class or who do not have a behavior disorder.

Facilities and infrastructure at this school are also still not friendly for children with special needs. This is evident from the stairs without a handrail. On the walls of the bathroom and the ablution area, there are still no handrails needed for children with physical disabilities. For the past 8 years there have not been students with special needs who need a hand grip to help balance their body, but it is possible in the coming years that students need a hand grip for their balance.

Based on existing records, in the last 1 year there were 2 complaints that were submitted by parents who have children with special needs because their children have received rough treatment from other children's parents who feel disturbed by the way children interact with special needs. In response to this, the school still has not taken steps to invite parents who have been abusive. The school still considers that these parents do not yet recognize the characteristics of children with special needs in this school, so there is an announcement from the school about the appearance of abusiveness. The school is still doing the apology stage for this unpleasant incident to parents who have children with special needs. In this case, a parenting system or a kind of periodic communication is needed for all parents to be able to understand the characteristics, regulations, or general conditions that exist in schools.

\section{The Challenges}

Based on some of the problems that are still being faced at this school, there are several challenges for this school that must be resolved. The first challenge is related to the willingness and intensity to build communication with the district education officer, so that various services for children with special needs can be done more optimally. Related to where alumni with special needs can attend secondary school at the junior high school level, it becomes a challenge for this school. Efforts to communicate with several junior high schools must be done by this school in order to establish good communication that builds the same understanding of the inclusion system. The second challenge is the implementation of the strengthening of the concept of preparing IEP for every child with special needs based on the short term, medium term, and long term. If this is not done immediately, the program for each student with special needs will be less organized. The third challenge is related to the concept of developing facilities and infrastructure in schools to create the concept of a school environment that is increasingly friendly to all children with special needs. The fourth challenge is that the form of communication and parenting system in this school needs to be 
optimized in order to create comfort and good services for all students and all school members.

\section{CORE DISCUSSION}

The enforcement of polite culture and the good will of inclusive implemented at Tabita Puri Elementary School turned out to be the main basic capital in the implementation of an inclusive education system. Because it was found that the reluctance of schools to accept students with special needs, especially with behavioral disorders is because teachers are reluctant to include students with behavioral disorders into their classess. As Sermier Dessemontet, Benoit, and Bless said (2011, in Lubke, Pinquart, \& Schwinger, 2018) that most of the teachers have negative attitudes towards the inclusion of students with behavioural problems and are less willing to include these children in their classes.

Inclusion applied in Tabita Puri Elementary School refers to the philosophy of sense of belonging, not to a place that gathers children with special needs and those who do not have special needs. Inclusion as defined by Goodall (2018) as being valued and wanted as a person by teachers, of fairness and of being supported by necessary support to access and drive in education. In short, inclusion is a feeling (a sense of belonging), not a place (mainstream or otherwise). We see that Tabita Puri Elementary School implements the development of character values, so this step strongly supports the application of inclusive education. Especially this school's step in implementing polite culture. As stated by Booth and Ainscow, it turns out that the inclusive education system does require the development of a school culture to be able to instill inclusive values. As proposed by Booth and Ainscow (2002, Carrington \& Macarthur, 2012: 347), there are 3 dimensions in the Index for Inclusion, that are culture, curriculum, and practice, which can be used as a framework for theoretical study and each dimension consists of 2 parts. These three things are (1) certain values must be developed in the creation of environment and culture in inclusive schools, this section contains (a) community development and (b) the determination of inclusive values; (2) strengthening the school policy system is also needed to help realize the inclusion goal which is divided into two parts, they are(a) developing schools for all and (b) organizing support for diversity; and (3) curriculum is an important part in carrying out the process of activities in inclusive programs, this section is divided into focus (a) managing learning and (b) mobilizing resources.

In addition, emphasizing the philosophy of inclusive education is also a top priority in this study. As confirmed by Ainscow, Slee, dan Best (2019), "... that policy is made at all levels of an education system, not least at the school and classroom levels". That it is necessary to formulate a policy that covers all levels of education. And therefore, according to Ainscow, Slee, dan Best (2019), "... the promotion of inclusion is not merely a technical or 
organizational change - it is a movement in a clear philosophical direction." Which can be interpreted by the assertion that the application of inclusion is not just a change techniques or organizational change, but the application of inclusion is a movement at a philosophical level with clear objectives. The inclusive movement thus requires "... shifts in policy-makers" values and ways of thinking, which enables them to provide a vision of shaping a culture of inclusion, through to significant changes within schools and classrooms. And, of course, this has to involve the wider community. "So it is clear that the implementation of inclusion requires a shift in values and ways of thinking at the level of policy makers, which directs them to provide a vision for shaping an inclusive culture, through significant changes in schooling and in classrooms, of course, and also must involve the wider community. Thus, the analysis of the implementation of inclusive education implementation must involve 3 dimensions (Ainscow, 2002; Carrington \& Macarthur, 2012: 346) they are culture, policy and practice.

Inclusive education is only part of a wider understanding of inclusion (Yvonne Becher and Zhang Li, 2010: 13, in Zidniyati, 2015). Regarding all the problems and challenges faced by Tabita Puri elementary schools or other schools that are implementing inclusion programs in schools or who are planning school programs to be more inclusive, there is an inclusion concept proposed by UNESCO that can be contradictory for Indonesia. Indonesia is a country that has norms that do not want freedom of sexual orientation. Freedom in sexual orientation is something that is not in accordance with the norms that exist in Indonesia Therefore this affirmation must be carried out in this study. In this research, the concept of inclusion is narrowed to the meaning of inclusion as a transformation process whose idea is to eliminate the exclusive process of education and negative attitudes or responses to diversity in debates with race, economic status, social class, relationships, religion, gender, language, and results, as well as those that discuss disability. Thus, the inclusion in this study is not as proposed in the meaning of inclusion which also gives freedom to the discussion requested by Azorin and Ainscow (2018) in citing the transformative inclusive conception by UNESCO. UNESCO issued the concept of transforming inclusion as an idea to eliminate the exclusive process of education and negative attitudes or responses to diversity in debates with race, economic status, social class, sexual orientation, ethnicity, religion, gender, language, and combinations, and those related to disability. In this study, it must be emphasized that agreement on the inclusion does not mean giving freedom of sexual orientation, because freedom of sexual orientation is contrary to the norms in Indonesia. The meaning of inclusion applied in Tabita Puri Elementary School and used in this study is a philosophy that humanizes students, both those with special needs and those without special needs can learn together and form a community of mutual respect.

\section{The Implementation of English Literacy in Tabita Puri Elementary School}


The application of English literacy in this school is still less successful compared to the application of character development and inclusive education. The effort made at this school is to provide English learning material for each class once a week for 1 hour of study. In addition there are extracurricular English class programs for all students in grades 1, 2 and 3 , which are conducted every two weeks for one hour of study.

For communication skills are still very low, because the communication program is still not implemented. There is one program planned at this school, which is communicating using English in 4 days during the school day, but it has not been implemented because the teacher's ability to communicate in English is still very weak.

\section{The Problems}

The lack of active English language skills from teachers raises its own obstacles in achieving the application of English literacy targets at Tabita Puri Elementary School. Efforts by the school include providing English language training to teachers on Saturdays for one hour. However, because the teacher's level of confidence is still lacking in communicating using English, finally on Monday to Friday, the teachers do not communicate in English. Another problem is, there are only two teachers who are able to actively communicate using English, and these two teachers have not been able to spread motivation to all school members to always practice communicating using English. Extracurricular activities to increase English learning hours for students are held every once a week. The activity which was held at the end of the semester in the form of market day activities, became the peak of English activity at this school. A sale and purchase activity, the seller and the buyer are school residents, who require all sellers and buyers to communicate in English. However, not all residents communicate in English.

\section{The Challenges}

Based on the problems that arise in Tabita Puri Elementary School, there needs to be seriousness from all school members in practicing communication in English. This has become a challenge for the school. In the era of digitalization like today the ability to communicate in English is very necessary. This school needs to adopt a natural English learning approach that makes all school members capable and motivated to communicate in English. At least every day there is an hour to communicate in English, or English is used as a medium of introduction to subject matter in addition to Indonesian. If English is used as one of the language of instruction in addition to Indonesian, every teacher needs to be given training more often, not only once a week. Another challenge for this school in getting all its 
citizens to speak English is to hold a variety of activities that require the ability to communicate in English.

\section{Core discussion}

The need for communication skills using English is very high at this time, especially 5 to 10 years into the future, when students who are currently still in elementary school have received higher education. The rate of economic acceleration is spurring the development of other fields, including education. If other fields go faster and faster, then the education sector must be the trigger for the rate. With a situation like this, international language skills, one of which is English can not be bargained anymore. Moreover, Banyuwangi Regency has become one of the cities with tourist destinations in the world. Efforts to extract information through internet network access are also easier for anyone. Most of the information on the internet, using international languages. one of them is English. How then ways and programs of English literacy developed in an elementary school in a fast-paced era such as in the 4.0 industrial revolution, will be the study of the formulation of management of English literacy in elementary schools in this research. Thompkins and Hoskisson (1995) explain various ways that elementary level students can enrich themselves through language learning. Thompkins and Hoskisson describe in detail how to hone the four language skills, namely speaking, listening, reading, and writing skills through various language activities in a language-rich learning environment setting. While Montessori (1917), also formulated in detail concrete ways and media that were able to facilitate students in learning English. Related to the English language skills possessed by Tabita Puri Elementary School teachers who are still low, while on the other hand, the teachers have dared to apply English learning in this school, so this is already a good effort. Given the demands of the continued development of the industrial revolution, English language skills must still be done.

\section{The Implementation of Inclusive Education by Strengthening Character Development and English Literacy in Elementary School in the Industrial Revolution Era}

The headmaster of Tabita Puri Elementary school said that everything that has been done by the Tabita Puri Elementary School is an effort to equip students to be able to live their life in the all-digital era. The inculcation of character-forming values, the application of the inclusion system, to the provision of English language skills is a series of efforts that this school is trying to do. According to researcher, all of these efforts are very appropriate, especially to deal with the era of the $4^{\text {th }}$ industrial revolution, as is the current situation. 
The term Industrial Revolution 4.0 (ir 4.0) was first introduced by Professor Klaus Schwab (2016), an economist through his book titled "The Fourth Industrial Revolution". The book reveals ideas from Schwab about the industrial revolution 4.0. Ir 4.0 is stated to have changed lives, mindsets to the workings of humans. In its development, the 4.0 industrial revolution provided (1) challenges as well as impacts on the young generation of the Indonesian nation and also (2) on the world of education in Indonesia. The development came with the start of digitizing the education system which directed every element in the education field to be able to make adjustments to the rate of change that occurred. One of several examples is the learning system in the classroom that has utilized the affordability of internet access. For example, by taking students exploring the virtual world to explore one or several information related learning materials in class.

When did the industrial revolution begin and why is it that suddenly our ears are familiar with the term industrial revolution 4.0. Are there previous industrial revolutions? Schwab (2016: 11) in his book outlines four eras that marked the stages of the industrial revolution as follows:

The first industrial revolution took place around the 18th century, in 1760 to 1840 marked by railroad construction and the invention of the steam engine (Schwab, 2016: 10). The emergence of the first steam engine led to the development of world economic progress. Inventions at this time led to a shift in power to mechanical production machines.

The second industrial revolution occurred in the late 19th century until the early 20th century, or around 1870 or known as the industrial revolution 2.0. During this era, mass production of various products emerged, driven by the emergence of electricity and assembly lines, including power plants, telephones, cars and airplanes.

The third industrial revolution occurred in the 1960s or around 1969 or known as the 3.0 industrial revolution. This period is often called the era of computer or digital revolution because of the acceleration of change with the development of semiconductors with mainframe computing. In this year the computer equipment appeared, although in a simpler ability than today. At this time emerged digital internet access which in turn has an influence on culture.

The fourth industrial revolution, known as the 4.0 industrial revolution, occurred in the 20th century. The generation that lives in this era is known as the $\mathrm{Z}$ generation or millennial generation. In the 20th century there has been a rapid development of technology and information compared to the previous period. Various information devices have used digital technology. Products that have emerged include smartphones with fairly sophisticated Android systems, mobile internet is everywhere with smaller sensors, with smaller and more powerful devices so that they become cheaper, and accompanied by artificial intelligence systems and machine learning systems. This sophistication is reflected by being able to use it 
as a remote communication tool and able to display visually the current situation of the communication user. In addition, everyone can access information, both disseminating and retrieving information easily and quickly, and efficiently both in terms of time and cost.

Along with the pace of life development in the industrial revolution era 4.0, the role of education must be strengthened by the concept of inclusive education. In the inclusion system, it is expected that character education will emerge that is able to revive the values of character builders in accordance with the characters needed in the era of the industrial revolution 4.0, an era that is completely digital. Two of the ten reasons proposed by Lickona, as quoted by Zidniyati (2017) about why schools must make clear and wholehearted commitments to teach moral values and develop good character is that the role of schools as moral educators becomes more important at a time of millions children get little moral learning from parents or less access from religious education centers in the mid-childhood years. A time when, children should get a moral example or character builder value from their immediate environment. One other strong reason proposed by Lickona (1991: 20) is because "there is no such thing as value-free education". The meaning is, all education units must teach values.

Teaching values is as ipotant as teaching skills for this era. As stated in the enGauge 21st Century Skill framework (Ari, 2018: 15) that there is a skill that students need to master, which is a high-level thinking skill. Ari et al explained that there were 4 skills included in the enGauge 21st Century Skill framework which later became known as the IP-21CSS (Indonesian Partnership for 21 Century Skill Standard) formula. The four skills are: (1) creativity thinking and innovation, (2) critical thinking and problem solving, (3) information, media and technology skills, and (4) life \& career skills.

The effort made by Tabita Puri Elementary School is an appropriate effort because it equips students with the character values needed to undergo the fast-paced advances in receiving digital information, where in that information, a student is required to be able to choose good things and avoid bad things. Character development which is the basis of inclusive education is able to provide briefing about the process of selecting information that must be followed and rejecting information that is not in accordance with the values adopted.

\section{The Result of The Research}

Based on observations on the activities conducted in learning-teaching program in the inclusive class by teachers, interviews with the informants, and observation based on some documents of learning plan made by the teachers at Tabita Puri Elementary School regarding the application of character education and English literacy in the inclusive education system in this school there are various levels of progress. For the development of character education 
occupies the highest level of success. This can be seen from the attitudes and behavior of every school member who is quite polite, habit of worshiping at school which is very good, as well as the concern of each school community to behave in polite manner among the member of school society which is quite good.

Based on observations, all students are willing, carrying out activities directed at the development of character education. The program at this school for character development at this school is an emphasis on habit of worship and habituation to be polite, speak polite words, love one another, and respect each other. In terms of habituation, all students have become accustomed to performing the routine of performing ablution, praying Dhuha, Dhuhur, and Asyar without any coercion from the teacher. This can be seen from all grade 1 to grade 6 students, totaling 106 students, who routinely carry out morning worship activities without the need to be forced by the teachers. Similarly, at worship in the afternoon and evening, all students carry out without coercion. Out of 106 students, there are only 2 students who still have to be accompanied in carrying out character development activities, especially for prayer and recitation. Two of these students did have special needs, one had ADHD disorders with lower average intellectuality, and the other experienced mild disability accompanied by behavioral disorders with borderline intellectuals. The results of interviews conducted by researchers of all teachers, and principals, there is data consistency. This can be seen in the explanation of grade 1 to grade 6 teachers and school principals who told that all students would immediately carry out worship activities without being forced. Only two students with ADHD and mild mental disabilities must be accompanied in every activity throughout the day. Based on the results of interviews with each teacher accompanying, there is data consistency regarding several aspects of research data. These aspects are: students with special needs experience progress in academia and behavior even though the speed is not as much as achieved by students who do not have special needs; the existence of students with special needs does not interfere with the process of students who do not have special needs in the learning process; all school residents get used to understanding students with special needs, all school people try to get used to being polite and polite so that all students are accustomed to carrying out character development programs.

Based on the observation of the learning plan document there are also several findings. 12 teachers have drawn up a lesson plan. However, the teacher only compiles 1 learning plan classically, the teacher still has not compiled an individual learning plan for students with special needs. In grade 4, which had 18 students, with 2 teachers, no distinction was found in learning plans for students with special needs. When learning takes place, class teachers deliver material according to the learning plan that has been prepared previously. Because there is no Individual Educational Program (IEP), students with special needs do not 
have individual programs. Because of no EIP that compiled by the teachers, some students with special needs cannot show any progress in some aspects.

Meanwhile, for English literacy activities at this school, it is done by providing special hours of English subjects as local content and providing extracurricular hours that must be followed by all students. English language skills should be given naturally, using communicative pragmatic principles. If this principle is applied, the application of all teachers has the ability to speak English actively and get used to inviting students to converse in English all the time. However, because not all teachers have active English language skills, English literacy activities are limited to English classes.

The following is an effort to see all the problems that occur at the study site. Habit of worship and attitude and polite words are always cultivated by the teacher to all students. Students always do routine activities of worship; keep themselves to be polite and polite. Culture of courtesy and obedience to worship is quite strong created in all school residents. Students who do not have special needs always calm students who have special needs who are crying, and remind students who have special needs to lower the volume so that the class situation continues to concentrate on learning activities in class. The teacher provides assistance. Meanwhile the teacher did not develop an Individual Learning Program for students with special needs. Based on all this information, of course, it can be decomposed one by one to dialogue on the relevant theory.

The level of success of the inclusive education system is need to be revised. Judging from the level of progress achieved every student with special needs in this school.. The application of English literacy occupied the lowest success compared to the character development program and the inclusion program.

Various successes and problems experienced by this school in the application of character education and English literacy in inclusive education systems produce various challenges. The challenges as outlined need to be addressed with various implications. Among the implications are (1) the need for more intensive support and communication development between the organizers of junior high schools and the local education office; (2) the need for periodic PPI preparation in accordance with short-term, medium-term and long-term targets; (3) the need to develop a concept of developing good communication and parenting systems between schools and parents; and (4) the need for the preparation of the concept of structuring facilities and infrastructure that is more friendly to all children.

A simplification can also be made about what has been discussed. The simplification is as follows: that in the implementation of inclusive education it turns out that it requires regular training and assistance to teachers in assisting students with special needs. The inclusive education provider school needs to arrange the curriculum so that all students are served. One way to do this is by developing an Individual Educational Program (IEP). The 
IEP is structured in order to provide plans for modifying material and accommodation or ways of achieving teaching materials to suit the abilities of children with special needs.

Thus, in this study an outline can be drawn regarding the implementation of inclusive education. Inclusive education will succeed when there are synergies between policy makers, schools, and homes. For the school that organize inclusive education, it must consider carefully the determination of the policies in force, the structuring of the curriculum, and the organizing practices in the whole teaching-learning process in the school.

\section{CONCLUSION}

Paying close attention to all the discussions that have been carried out in this study, it can be concluded that some of the problems that have caused constraints in the implementation of inclusion in Tabita Puri Elementary School are: (a) lack of communicating between the the local education office or the policy makers in the regions regarding the implementation of inclusive education, (b) lack of teacher ability in accompanying students in inclusive schools and the lack of teacher skills in English, (c) some parents who disagree with the mixing of students with special needs and those without special needs, and (d) the lack of paraprofessionals needed in carrying out some of the interventions needed in organizing inclusion.

On the other hand, there are a number of things that ultimately support the implementation of inclusive education is the emergence of the goodwill of policy makers and schools in implementing the implementation of inclusive education and efforts to develop character education in inclusive schools, despite the various problems that surround it. This good intention is already a big capital for the implementation of inclusive education. Based on all of these issues and support, the challenges to organizing inclusive education in the future are (a) building effective communication with the local education office, (b) strengthening teacher skills in implementing inclusive education programs and in English language skills, (c) convincing parents that the inclusive education system is a very appropriate system for instilling the values of togetherness, justice, respect, empathy, sense of belonging, and mutual respect for all school members. The important thing that can be concluded is that the implementation of inclusive education will be successful when there is synergy and common understanding from the stakeholders, schools, homes, and professionals.

\section{REFERENCES}

Ainscow, M., Slee, R. \& Best, M. (2019). Editorial: the Salamanca Statement: 25 years on, International Journal of Inclusive Education, 23:7-8, 671-676, DOI: $\underline{10.1080 / 13603116.2019 .1622800}$ 
Boot, T. \& Ainscow, M. (2002). Index for inclusion developing learning and participation in schools. Bristol (England): CSIE (Centre for Studies on Inclusive Education)

Carrington, Suzanne \& Macarthur, Jude. (2012). Teaching in inclusive school communities. John Wiley \& Sons Australia, Ltd.

Cecilia Azorín \& Mel Ainscow (2018): Guiding schools on their journey towards inclusion, International Journal of Inclusive Education, DOI: $\underline{\text { 10.1080/13603116.2018.1450900 }}$

Drake, Christopher. (2016). Values education-principle and practice. Proceeding The $3^{\text {rd }}$ Summit Meeting on Education International Seminar Values-Based Learning for Wonderful Children. Yogyakarta, November 22nd 2016. ISBN 978-602-74934-3-8.

Depiyanti, O. M. (2014). Model Pendidikan Karakter di Islamic Full Day School (Studi Deskriptif pada SD Cendekia Leadership School, Bandung). TARBAWY: Indonesian Journal of Islamic Education, 1(2), 132-141.

Goodall, Craig. (2018): Inclusion is a feeling, not a place: a qualitative study exploring autistic young people's conceptualisations of inclusion, International Journal of Inclusive Education, DOI: $\underline{10.1080 / 13603116.2018 .1523475}$

Heafford, M.R. (1967). Pestalozzi, his thought and its relevance today. London: Methuen \& Co Ltd.

Hornby, Garry.(2014) Inclusive special education:evidence-based practices for children with special needs and disabilities. New York: Springer.

Ki Hadjar Dewantara. (2013). Bagian pertama: pendidikan. Jogjakarta: Majelis Luhur Persatuan Taman Peserta didik.

Kirschenbaum, Howard. (1995). 100 ways to enhance values and morality in schools and youth settings. Boston: Allyn and Bacon.

Lickona, Thomas. (1992). Educating for character. Canada: Bantam books

Laura Lübke, Martin Pinquart \& Malte Schwinger (2018): How to measure teachers' attitudes towards inclusion: evaluation and validation of the Differentiated Attitudes Towards Inclusion Scale (DATIS), European Journal of Special Needs Education, DOI: $\underline{10.1080 / 08856257.2018 .1479953}$

Montessori. (1917). The advanced Montessori method: the Montessori elementary material. Translated from the Italian by Arthur Livingstone, Associate Professor of Italian at Columbia University. Neyw York: Frederick A. Stokes Company Publishers.

Murniyetti, M., Engkizar, E., \& Anwar, F. (2016). Pola pelaksanaan pendidikan karakter terhadap siswa sekolah dasar. Jurnal Pendidikan Karakter, 6(2).

Schwab, Klaus. (2016). The fourth industrial revolution. Geneva: World Economic Forum. 
The Dinamics od Integrated Character Development \& English Literacy....

Tillman, Diane G. (2016). The important of living value education for children. Proceeding The 3rd Summit Meeting on Education International Seminar Values-Based Learning for Wonderful Children. Yogyakarta, November 22nd 2016. ISBN 978-602-74934-3-8.

Tillman, Diane G. (2005). Living values: an educational progam; living values activities for children ages 8-14. Pendidikan nilai untuk anak usia 8-14 tahun. Alih bahasa oleh Adi Respati dkk. Jakarta: PT Grasindo.

Shaeffer, Sheldon. 2010. Inclusion and early childhood care and development. Artikel dalam jurnal Asia-Pacific Regional Network for Early Childhood, volume 3. Singapore: ARNEC.

Wasitohadi. (2014). Hakekat pendidikan dalam perspektif John Dewey: tinjauan teoretis. Article dalam ejounal.uksw.edu. Vol 30 No 1 Juni 2014. Satya Widya, Jurnal Penelitian Pengembangan Kependidikan FKIP UKSW Salatiga. ISSN 0854-5995. https://doi.org/10.24246/j.sw.2014.v30.i1.p49-61

Zamroni dkk. (2018). Buku pegangan berorientasi pada keterampilan berpikir tingkat tinggi. Jakarta: Direktorat Jenderal Guru dan Tenaga Kependidikan-Kementrian Pendidikan dan Kebudayaan.

Zidniyati. (2015). Creating learning environment in elementary school/islamic elementary school based on integrated-thematic approach in inclusion class. Proceeding International Conference of Islamic Education: reforms, prospects, and challenges (ICIED). ISSN: 2477-3638. p. 236-246. Malang: FITK UIN Maliki.

Zidniyati. (2017). The implementation of values comprehensive approach in developing character in an elementary school in Banyuwangi (an observational report). Proceeding International Conference on Islamic Education (ICIED), [S.l.], v. 2, n. 1, p. 286-298, nov. 2017. 